\title{
Interactive comment on "On the model uncertainties in Bayesian source reconstruction using the emission inverse modelling system FREARtool v1.0 and the Lagrangian transport and dispersion model Flexpart v9.0.2" by Pieter De Meutter et al.
}

Pieter De Meutter et al.

pieter.de.meutter@sckcen.be

Received and published: 6 November 2020

Dear Reviewer 2,

We would like to thank you for your in-depth review and interesting thoughts. We believe that your comments and suggestions will help us to improve our manuscript. Please find attached a reply to your comments and suggestions. We have also added plots similar to Fig 4 at the end of the file, for all observations and all release time 
intervals $(12 * 24=288$ figures in total).

Yours faithfully, The authors

Please also note the supplement to this comment:

https://gmd.copernicus.org/preprints/gmd-2020-162/gmd-2020-162-AC2-

supplement.pdf

Interactive comment on Geosci. Model Dev. Discuss., https://doi.org/10.5194/gmd-2020-162, 2020. 